\title{
SOSIALISASI PERENCANAAN DESAIN IPLT BUMI AYU KABUPATEN PRINGSEWU
}

\author{
Mirnanda Cambodia*1, Elza Novilyansa² ${ }^{2}$ Yunita Mauliana ${ }^{3}$ \\ ${ }^{123}$ Universitas Sang Bumi Ruwa Jurai \\ e-mail: *11mirnanda.cambodia.mc@gmail.com, ${ }^{2}$ novilyansa@gmail.com, ${ }^{3}$ yunita.mauliana@gmail.com
}

\begin{abstract}
Abstrak
Tujuan kegiatan pengabdian ini adalah melaksanakan sosialisasi mengenai Perencanaan Desain Instalasi Pengelolaan Limbah terpadu (IPLT) di Bumi Ayu Kabupaten Pringsewu. Metode yang digunakan adalah sosialisasi dan pendampingan terhadap masyarakat setempat. Hasil pengabdian ini diperoleh kesimpulan bahwa Sosialisasi Perencanaan Desain IPLT sebagai upaya pelaksanaan pembangunan fisik optimalisasi IPLT Bumi Ayu dapat terlaksana secara optimal sesuai dengan standar teknis yang disyaratkan. Untuk mendorong optimalisasi pengolahan lumpur tinja di IPLT Bumi Ayu serta menjawab kebutuhan akan pengolahan yang lebih besar dimasa mendatang yaitu 164 m3/hari IPLT Bumi Ayu perlu ditingkatkan kapasitas pengolahannya hingga 55 m3/hari. Ada beberapa prioritas strategi yang dapat dilakukan antara lain penambahan bangunan SSC (Solid Separation Chamber), memperluas bangunan SDB (Sludge Drynig Bed), perbaikan dan pemeliharaan komponen bangunan eksisting serta uji kebocoran pada bangunan-bangunan kolam eksisting.
\end{abstract}

Kata kunci : IPLT Bumi Ayu, Limbah, Lumpur Tinja

Abstract
The purpose of this service activity is to carry out socialization regarding the Integrated Waste Management Installation Design Planning (IPLT) in Bumi Ayu, Pringsewu Regency. The method used is socialization and assistance to the local community. The results of this service concluded that the socialization of the IPLT design planning as an effort to implement the physical development of the optimization of the Bumi Ayu IPLT can be carried out optimally in accordance with the required technical standards. To encourage the optimization of sewage treatment at the Bumi Ayu IPLT and to answer the need for a larger treatment in the future, namely $164 \mathrm{m3} /$ day, the Bumi Ayu IPLT needs to increase its processing capacity to $55 \mathrm{m3} /$ day. There are several strategic priorities that can be carried out, including the addition of SSC (Solid Separation Chamber) buildings, expanding SDB (Sludge Drynig Bed) buildings, repair and maintenance of existing building components and leak testing on existing pool buildings.

Keywords : Bumi Ayu IPLT, Waste, Sludge

\section{PENDAHULUAN}

Kabupaten Pringsewu merupakan Kabupaten Pertama di Provinsi Lampung yang telah mencapai status bebas buang air besar sembarangan atau open defecation free (ODF) sejak tahun 2017 [1]. Kondisi ini mendorong peningkatan jumlah infrastruktur sanitasi khususnya toilet dan penampungan tinja di masyarakat. Selain itu, peningkatan sarana penampungan tinja akan berdampak meningkatnya kebutuhan akan penyedotan lumpur tinja di masa depan. Mengacu kepada Peraturan Menteri PUPR No 04 Tahun 2017, dimana setiap rumah tangga wajib melakukan penyedotan tangki septik paling tidak 3 tahun sekali, sehingga diperlukan tersedianya instalasi pengolahan lumpur tinja (IPLT) yang berfungsi 
serta terkelola secara baik sehingga memberikan jaminan pengelolaan yang aman dan mengurangi pencemaran lingkungan di sekitar IPLT [2].

Kabupaten Pringsewu memiliki luas wilayah kurang lebih $625 \mathrm{Km}^{2}$ dengan jumlah penduduk 401.230 jiwa yang terbagi menjadi 9 kecamatan, 5 kelurahan dan 126 desa [3]. Untuk pengolahan lumpur tinja, Kabupaten Pringsewu memiliki sebuah IPLT Bernama IPLT Bumi Ayu. Lumpur tinja merupakan air limbah yang dalam proses pembusukannya akan menguraikan zat organik yang dikandungnya dan menghasilkan gas yang berbau dan dapat menimbulkan polusi bagi lingkungan. Lumpur tinja mengandung berbagai mikroorganisme patogen yang berasal dari sistem pencernaan manusia [4].

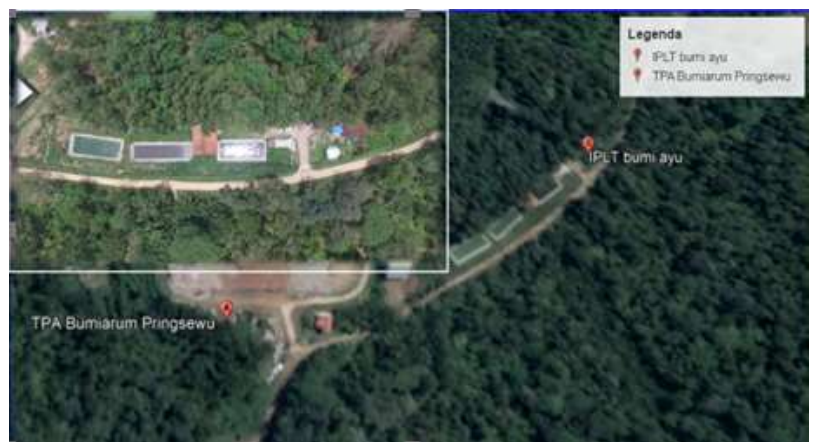

Gambar 1. Lokasi IPLT Bumi Ayu

IPLT merupakan instalasi pengolahan air limbah yang didesain hanya menerima lumpur tinja [5]. Lumpur tinja di ambil dari unit pengola limbah tinja seperti tangki septik dan cubluk tunggal atau pun endapan lumpur dari underflow unit pengolahan air limbah lainya. IPLT di rancang untuk mengolah lumpur tinja sehingga tidak membahayakan bagi kesehatan masyarakat dan lingkungan sekitarnya [6]. Sehingga tangki septik dapat berfungsi kembali sebagaimana mestinya [7]. IPLT dapat memberikan potensi adanya pencemaran tinja pada perairan [8].

Berdasarkan data di atas, timbulan lumpur tinja yang dihasilkan adalah $200.51 \mathrm{~m}^{2}$ /hari dan akan bertambah seiring dengan pertumbuhan penduduk serta pengembangan pembangunan kabupaten ke depan. IPLT Bumi Ayu dibangun tahun 2014 dengan kapasitas olahan $15 \mathrm{~m}^{3} /$ hari atau 5 truk dengan kapasitas 3 $\mathrm{m}^{3}$. Sebagai pelaksana pengelolaan lumpur tinja baik layanan ataupun sarana IPLT, Kabupaten Pringsewu telah membentuk Unit Pelaksana Teknis (UPT) IPLT pada Dinas Lingkungan Hidup berdasarkan Peraturan Bupati Kabupaten Pringsewu (Perbup) No.34 tahun 2015. Kemudian mengalami perubahan pada 2020, yakni UPTD telah berpindah di bawah naungan Dinas Pekerjaan Umum dan Perumahan Rakyat Kabupaten Pringsewu menjadi UPTD Pengelolaan Air Limbah [9].

Hingga saat ini, lumpur yang diolah di IPLT masih di bawah kapasitas olahan yang dimiliki sehingga perlu dilakukan upaya agar IPLT dapat berfungsi secara optimal [10]. Sebagai upaya untuk meningkatkan kinerja IPLT dan pengelolaannya, Kabupaten Peringsewu menyusun dokumen kajian strategis IPLT yang dapat memberikan gambaran tentang kondisi saat ini termasuk permasalahan yang ada sehingga dapat menghasilkan rencana-rencana strategis untuk perbaikan dengan tujuan untuk mengoptimalkan pengolahan lumpur tinja di 
IPLT Bumi Ayu Kabupaten Pringsewu. Sehingga tujuan kegiatan pengabdian ini adalah melaksanakan sosialisasi mengenai Perencanaan Desain Instalasi Pengelolaan Limbah terpadu (IPLT) di Bumi Ayu Kabupaten Pringsewu terhadap masyarakat setempat.

\section{METODE}

\subsection{Metode yang digunakan}

Dalam pelaksanaan kegiatan pengabdian pada masyarakat ini, metode yang digunakan adalah sosialisasi di lokasi terkait perencanaan desain instalasi pengelolaan limbah terpadu (IPLT) Bumi Ayu, Kabupaten Pringsewu. Metode ini dilakukan dengan tujuan untuk memberikan arahan dan informasi kepada masyarakat terkait pentingnya pengelolaan lumpur tinja di lokasi sekitar IPLT Bumi Ayu Kabupaten Pringsewu.

\subsection{Jadwal Kegiatan}

Kegiatan pengabdian kepada masyarakat dilaksanakan selama 3 bulan yaitu bulan Juli 2020 s/d September 2020 bertempat di lokasi sekitar IPLT Bumi Ayu Kabupaten Pringsewu. Adapun rincian kegiatan sebagai berikut :

Tabel 1. Jadwal Kegiatan

\begin{tabular}{lcccc}
\hline & \multirow{3}{*}{ Uraian } & \multicolumn{3}{c}{ Bulan } \\
\cline { 3 - 5 } No & Kegiatan & Juli & Agustus & September \\
& & 2020 & 2020 & 2020
\end{tabular}

\begin{tabular}{l}
\hline Penyusunan \\
Laporan
\end{tabular}
2. Persiapan
Kegiatan
3. Pelaksanaan
Kegiatan
4. Pelaporan

Keterangan :

a. Penyusunan proposal kegiatan dilakukan sebagai tahap pertama pengajuan program pengabdian masyarakat.

b. Persiapan kegiatan sosialisasi yang dilakukan dilanjutkan dengan pengumpulan materi- materi sosialisasi.

c. Sosialisasi yang akan dilakukan meliputi kegiatan pemaparan materi kepada instansi terkait baik Dinas Lingkungan Hidup Provinsi dan Juga Dinas Lingkungan Hidup Kabupaten serta masyarakat di lokasi pengabdian.

d. Pelaporan hasil kegiatan akan dilakukan sebagai bentuk pertanggungjawaban atas kegiatan.

\section{HASIL DAN PEMBAHASAN}

Kegiatan berlangsung dalam beberapa tahapan, tahapan pertama adalah persiapan kegiatan untuk berkoordinasi dengan berbagai pihak yang terkait. Mengingat sangat banyaknya pihak-pihak yang terkait dalam kegiatan ini tahap persiapan ini harus direncanakan dengan matang. Survey ke lokasi dilakukan untuk mengetahui dan melihat secara detail tentang kondisi eksisting IPLT dan keberfungsian setiap 
komponen pengolahan yang terdapat di IPLT Bumi Ayu Kabupaten Pringsewu.

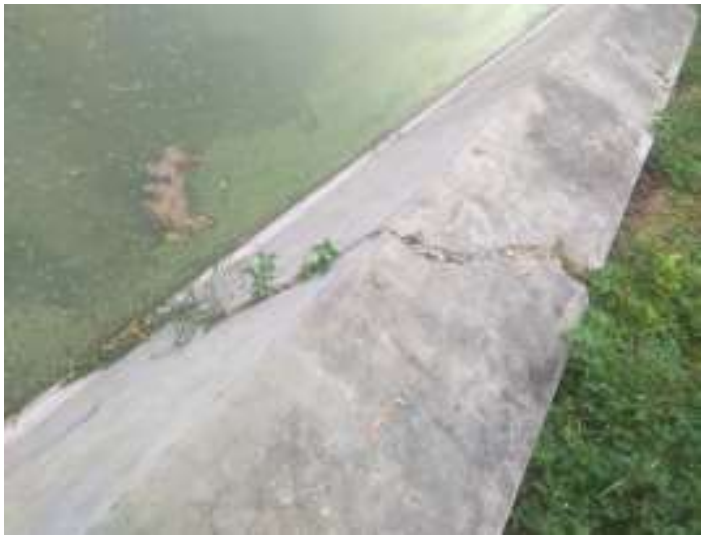

Gambar 2. Terjadi keretakan

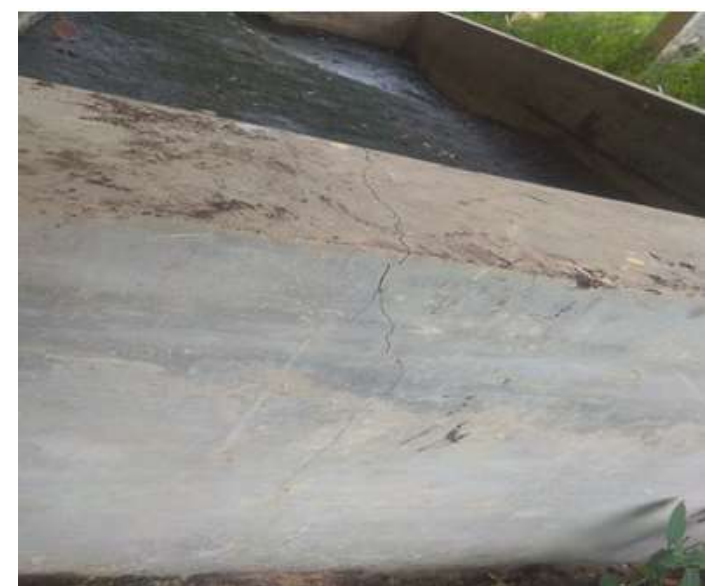

Gambar 3. Terjadi keretakan di beberapa sisi

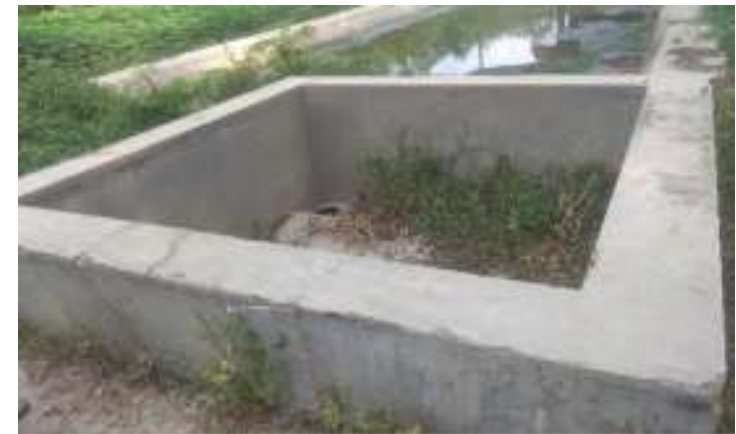

Gambar 4. Tumbuhnya Ilalang dan rumput liar

Dari Gambar 2, Gambar 3 dan Gambar 4 di atas terlihat bahwa kondisi kondisi existing dari instalasi pengolahan limbah terpadu yang ada di Desa Bumi Ayu Kabupaten Pringsewu terjadi keretakan atau patah pada komponen bangunan kolamnya serta terdapat ilalang dan rumput liar yang mengakibatkan terhambatnya proses pengolahan lumpur tinja dan dapat mengganggu proses pemindahan lumpur tinja dari bak penerima ke kolam anaerob.

Hasil observasi di lokasi terkait kondisi existing dari komponen bangunan kolam pengolahannya, disampaikan pada saat sosialisasi kepada masyarakat terkait hal-hal apa saja yang sekiranya dapat diperbaiki dalam merencanakan desain Instalasi Pengolahan Limbah terpadu (IPLT) di Bumi Ayu. Selain itu, kegiatan sosialisasi juga dilakukan untuk memberikan pengarahan kepada masyarakat sekitar lokasi IPLT terkait pentingnya bangunan pengolahan Limbah tersebut.

Secara umum kegiatan ini sudah berjalan dengan sangat baik, pihak pejabat di lokasi dengan maksimal membantu tim dalam melaksanakan kegiatan ini. Namun karena kegiatan ini diadakan ditengah pandemi, banyak kendala yang dialami, terutama jumlah masyarakat yang ikut dalam kegiatan sosialisasi jumlahnya dibatasi kurang leih sekitar 20 orang. Oleh karena itu, masyarakat yang diundang adalah orang-orang yang dianggap mampu dan paham mengenai pengolahan lumpur tinja sehingga nantinya merekalah yang melanjutkan apa yang sudah diperoleh kepada masyarakat yang lainnya.

Untuk timbulan lumpur tinja dimasa mendatang pada lokasi pengabdian dihitung menggunakan persamaan berikut ini [6] : 


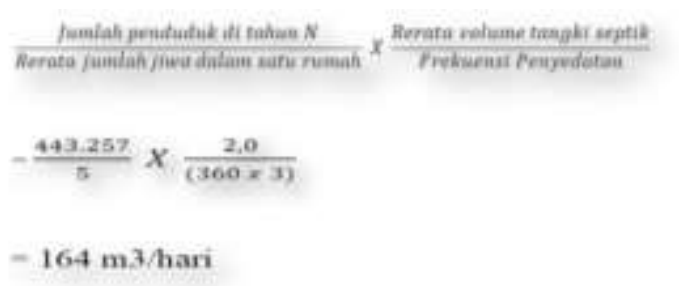

Dari hasil persamaan di atas, diperoleh kebutuhan pengolahan sebesar $164 \mathrm{~m}^{3} /$ hari di masa mendatang di IPLT Bumi Ayu sehingga perlu ada peningkatan kapasitas pengolahannya hingga $55 \mathrm{~m}^{3} /$ hari. Untuk mencapai hal tersebut, ada beberapa prioritas strategi yang dapat dilakukan antara lain penambahan bangunan SSC (Solid Separation Chamber), memperluas bangunan SDB (Sludge Drynig Bed), perbaikan dan pemeliharaan komponen bangunan eksisting serta uji kebocoran pada bangunan-bangunan kolam eksisting.

\section{SIMPULAN}

Setelah melakukan kegiatan pengabdian ini disimpulkan bahwa mayoritas responden antusias dalam sosialisasi untuk mendorong optimalisasi pengolahan lumpur tinja di IPLT Bumi Ayu serta menjawab kebutuhan akan pengolahan yang lebih besar dimasa mendatang yaitu $164 \mathrm{~m} 3 /$ hari IPLT Bumi Ayu perlu ditingkatkan kapasitas pengolahannya hingga 55 $\mathrm{m} 3 /$ hari. Ada beberapa prioritas strategi yang dapat dilakukan antara lain penambahan bangunan SSC (Solid Separation Chamber), memperluas bangunan SDB (Sludge Drynig $B e d)$, perbaikan dan pemeliharaan komponen bangunan eksisting serta uji kebocoran pada bangunan-bangunan kolam eksisting.

\section{SARAN}

Berdasarkan hasil pengabdian ini sebagaimana telah disimpulkan di atas, Tim Pengabdi dapat menyusun beberapa saran dan rekomendasi kepada instansi terkait, diantaranya adalah sebagai berikut:

1. Perlunya kegiatan pendampingan sejenis secara rutin dari civitas akademika kepada masyarakat terkait instalasi pengolahan limbah yang baik dan tepat.

2. Diperlukan sinergisitas antara Pemerintah Daerah dan semua elemen masyarakat untuk secara rutin melakukan pendampingan kepada masyarakat di wilayahnya terkait instalasi pengolahan limbah yang baik dan tepat.

3. Diperlukan alokasi program khusus untuk pendampingan sebagai bagian dari pengabdian kepada masyarakat (PKM) oleh Universitas Sang Bumi Ruwa Jurai sebagai implementasi Tri Dharma Perguruan Tinggi.

\section{UCAPAN TERIMA KASIH}

Penulis mengucapkan terima kasih kepada Dinas Lingkungan Hidup, Dinas PUPR, Dinas Kesehatan, UPT Air Limbah dan Operator IPLT Kabupaten Pringsewu yang telah bersedia 
diwawancarai sebagai dukungan terhadap program pengabdian masyarakat ini.

\section{DAFTAR PUSTAKA}

[1] I. N. Yusadireja, R. Setiawati, and SNV, "Studi Formatif untuk Perilaku Buang Air Besar Sembarangan (BABS) Kabupaten Pringsewu dan Lampung Selatan Provinsi Lampung," 2017.

[2] Permen PUPR, Peraturan Menteri PUPR No. 4. 2017.

[3] BPS Kabupaten Pringsewu, Kabupaten Pringsewu dalam Angka 2020. 2020.

[4] N. Mulyani and M. Solikhin, "Perencanaan Instalasi Pengolahan Lumpur Tinja (IPLT) Babakan Karet Kabupaten Cianjur Menggunakan Kolam Stabilisasi Tahun 2017," J. Teknol. dan Pengolah. Lingkung., vol. 5, no. 2, pp. 24-39, 2018.

[5] A. Hasanah, D. A. Nindito, and I. M. Kamiana, "Studi Perencanaan Instalasi Pengolahan Lumpur Tinja (IPLT) Kuala Kapuas Kabupaten Kapuas,” 2017.

[6] Yeni Pratiwi, "Analisis Kebutuhan Instalasi Pengolahan Lumpur Tinja (IPLT) di Kabupaten Blitar,”p. 12, 2019.

[7] M. D. S. Pradana and H. D. P. Priambodo, "Tinja Balai Pengelolaan Infrastruktur Air Limbah Dan Air Minum ( Pialam ) Daerah Istimewa Yogyakarta," J. Purifikas, vol. 19, no. 2, pp. 53-58,
2019.

[8] D. R. Rianto, Haeruddin, and S. Febrianto, "Distribusi Spasial Amonia, Nitrit, dan Escherichia Coli dari Limbah Instalasi Pengolahan Lumpur Tinja (IPLT) Tanggung Rejo, Kota Semarang," J. Maquares, vol. 7, no. 2, pp. 181-188, 2018.

[9] Perbup Pringsewu, "Peraturan Bupati Pringsewu Nomor 38 Tahun 2015,” 2015.

[10] Direktorat Pengembangan Penyehatan Lingkungan Permukiman Kementerian Pekerjaan Umum dan Perumahan Rakyat, "Pedoman Perencanaan Teknik Terinci Instalasi Pengolahan Lumpur Tinja (IPLT)," pp. 1-89, 2018. 